\title{
STUDI PENURUNAN ZAT WARNA ACID ORANGE 7 DENGAN PROSES OKSIDASI MENGGUNAKAN FERRAT $\left(\mathrm{FeO}_{4}\right)^{2-}$
}

\author{
Dian Windy Dwiasi dan Suyata \\ Program Studi Kimia, Jurusan MIPA, Fakultas Sains dan Teknik, UNSOED
}

\begin{abstract}
Colour removal from textile wastewater has been a matter of considerable interest during the last two decades, not only because of the potential toxicity of certain dyes but often due to their visibility in receiving waters and to their low biodegradability. Due to the limited success of some physical and chemical techniques for the treatment of dye effluents it is necessary to develop destructive systems leading to complete mineralization or, at least, to less harmful or easy-to-treat compounds. Oxidation processes using ferrate $\left(\mathrm{FeO}_{4}\right)^{2-}$ have been found to be very effective in the degradation of dye pollutants and for the treatment of waste waters from the textile industry.

Acid Orange 7 (AO7) commonly used as a textile dye and could be degraded by ferrate oxidation processes. In the oxidation degradation of dye by ferrate process, effect of some parameters such as time, $\mathrm{pH}$, and molar ratio of dye was examined at experimental condition. AO7 removal by this process was calculated to be equal to 12 minute at experimental condition. Ferrate can oxidize acid orange 7 effectively at optimum $\mathrm{pH}$ of 9.8 , with the molar ratio of ferrate : acid orange 7 at $4: 1$. The percentages of acid orange 7 degradation reached to $98.9 \%$.
\end{abstract}

Keywords : Acid Orange 7, ferrate, proses oksidasi

\section{PENDAHULUAN}

Oksidasi merupakan salah satu reaksi kimia penting. Spesies yang diperlukan untuk melakukan oksidasi suatu senyawa disebut dengan oksidator. Suatu spesies dapat dikatakan sebagai oksidator apabila spesies tersebut mengandung atom dengan bilangan oksidasi tinggi (Daintith, 2005). Oksidator antara lain dapat digunakan dalam pengolahan limbah, atau dapat juga digunakan untuk mengoksidasi suatu senyawa guna mendapatkan senyawa baru yang dapat digunakan dalam penelitian. Contoh oksidator yang banyak dipakai adalah $\left(\mathrm{Cr}_{2} \mathrm{O}_{7}\right)^{2-},(\mathrm{Cr})^{6+}, \mathrm{MnO}_{4}^{-}$, $(\mathrm{Mn})^{7+}, \quad \mathrm{H}_{2} \mathrm{O}_{2}, \quad \mathrm{HNO}_{3}$ dan lain-lain. Namun oksidator-oksidator ini tidak ramah lingkungan karena bersifat toksik. Oksidator-oksidator alternatif lainnya adalah brom, yodium, klor dioksida, kloramin dan ozon. Namun oksidatoroksidator tersebut membentuk hasil samping yang cukup besar, beberapa diantaranya beracun di lingkungan akuatik dan manusia (Panagiota and Graham 2002). Oleh karena itu, diperlukan suatu oksidator yang bersifat ramah lingkungan atau tidak mencemari lingkungan, serta efektif dalam mengoksidasi senyawa pencemar yaitu $\mathrm{K}_{2} \mathrm{FeO}_{4}$ atau dalam bentuk ionnya adalah $\left(\mathrm{FeO}_{4}{ }^{2-}\right)$.

$\mathrm{Fe}(\mathrm{VI})$ dalam bentuk kalium ferrat $\left(\mathrm{K}_{2} \mathrm{FeO}_{4}\right)$ merupakan oksidator dan telah banyak penelitian yang menggunakan senyawa ini sebagai agen pengoksidasi dalam air dan pengolahan limbah cair (Jiang and Lloyd, 2002). Sebagai oksidator dalam air, Fe(VI) direduksi menjadi $\mathrm{Fe}(\mathrm{III})$ atau produk akhir yang tidak larut dalam air $\left(\mathrm{Fe}[\mathrm{OH}]_{3}\right)$ (Sharma, 2007). Keuntungan yang diharapkan adalah proses pengolahan air dan limbah cair dapat menghasilkan produk (air bersih) dengan kualitas yang lebih baik (resiko 
pembentukan hazardous byproduct lebih kecil) dan biaya operasional yang lebih kecil.

Dwiasi (2008) telah melakukan penelitian tentang aplikasi ferrat terhadap degradasi zat warna azo yang banyak digunakan dalam industri, yaitu methyl orange. Dari penelitian yang telah dilakukan, diperoleh hasil bahwa ferrat sangat efektif dalam mendegradasi zat warna tersebut. Hal ini ditandai dengan proses degradasi yang berlangsung cepat mulai dari awal ferrat dikontakkan dengan zat warna. Persentase degradasi methyl orange mencapai $100 \%$. Xu et al (2009) meneliti tentang degradasi zat warna azo aktif brilliant red X-3B menggunakan larutan komposit ferrat. Berdasarkan pernyataan tersebut maka dalam penelitian ini akan dilakukan aplikasi ferrat untuk proses degradasi zat warna Acid orange 7.

\section{METODE PENELITIAN \\ Bahan dan Alat}

Bahan-bahan yang digunakan dalam penelitian ini adalah Kalium ferrat $\left(\mathrm{K}_{2} \mathrm{FeO}_{4}\right)$, Acid orange $7, \mathrm{NaH}_{2} \mathrm{PO}_{4} 0,2$ $\mathrm{M}, \mathrm{Na}_{2} \mathrm{HPO}_{4}$ 0,2 $\mathrm{M}, \mathrm{Na}_{2} \mathrm{~B}_{4} \mathrm{O}_{7}$ 0,2 $\mathrm{M}$, glasswool, Akuabides (Laboratorium Kimia Analitik MIPA UNSOED), $\mathrm{HCl}$ dan $\mathrm{NaOH}$ yang dipakai untuk mengatur $\mathrm{pH}$ larutan menjadi alkalis.

Peralatan yang digunakan dalam penelitian ini meliputi peralatan gelas: gelas beker, tabung reaksi, labu takar, corong gelas dan cawan arloji. Pemindahan larutan dilakukan dengan pipet tetes dan pipet volume. penyimpan produk digunakan vacuum desiccator. Spektrofotometer UV-Vis, $\mathrm{pH}$ meter, pengaduk magnet, centrifugator, vortex, kertas saring.

\section{Prosedur Penelitian}

\section{Sintesis kalium ferrat $\left(\mathrm{K}_{2} \mathrm{FeO}_{4}\right)$}

Sebanyak $40 \mathrm{~mL}$ larutan $\mathrm{NaOCl}$ direaksikan dengan 12 gram $\mathrm{KOH}$. Larutan diaduk hingga semua $\mathrm{KOH}$ larut sempurna, kemudian ditambah $1 \mathrm{~mL}$ $\mathrm{Fe}\left(\mathrm{NO}_{3}\right)_{3}$ dan diaduk kembali hingga larutan berwarna ungu. Larutan ditutup rapat kemudian didiamkan selama satu hari. Pada kondisi ini ion $\mathrm{Fe}(\mathrm{III})$ dioksidasi menjadi $\mathrm{Fe}(\mathrm{VI})$ dan larutan menjadi berwarna ungu gelap. Sementara itu disiapkan larutan $\mathrm{KCl}$ 0,3 $\mathrm{M}$ dengan melarutkan 1,175 gram $\mathrm{KCl}$ dalam labu takar $50 \mathrm{~mL}$. Selanjutnya diambil larutan $\mathrm{KCl}$ sebanyak $30 \mathrm{~mL}$ dalam gelas Erlenmeyer. Larutan ferrat yang telah didiamkan selama sehari tadi pada preparasi sebelumnya disaring dengan glasswool di atas Erlenmeyer yang berisi larutan $\mathrm{KCl}$. Setelah itu erlenmeyer ditutup dan larutan didiamkan lagi selama beberapa hari. Selanjutnya campuran disentrifugasi selama 10 menit dengan kecepatan 2000 rpm. Endapan dipisahkan dari larutan, kemudian dikeringkan di bawah lampu pijar hingga air yang masih terkandung di dalamnya hilang. Produk akhir yang diperoleh yaitu padatan hitam kalium ferrat kemudian dikumpulkan dan disimpan dalam vacuum desicator untuk perlakuan selanjutnya.

\section{Penentuan pH optimum degradasi}

Penentuan $\mathrm{pH}$ optimum dilakukan dengan membuat perbandingan $\mathrm{Fe}(\mathrm{VI})$ : zat warna azo $=5: 1$. Sebanyak $1 \mathrm{~mL}$ larutan ferrat konsentrasi $1,275 \times 10^{-4} \mathrm{M}$ dan zat warna azo konsentrasi 2,55 x $10^{-5}$ $\mathrm{M}$, diatur pH-nya $8-10$ dengan menambahkan buffer, kemudian larutan dikocok. Larutan diukur absorbansinya dengan spektrofotometer UV-Vis pada panjang gelombang zat warna azo.

\section{Penentuan rasio molar optimum}

Penentuan rasio molar optimum dilakukan dengan variasi rasio molar $\mathrm{Fe}(\mathrm{VI})$ : zat warna azo $=1-5: 1$. Sebanyak $1 \mathrm{~mL}$ larutan ferrat dan zat warna azo dengan konsentrasi pada rasio molar yang diinginkan, ditambahkan buffer pada $\mathrm{pH}$ optimum. Kemudian 
larutan dikocok. Larutan diukur absorbansinya dengan spektrofotometer UV-Vis pada panjang gelombang zat warna azo.

\section{Degradasi zat warna azo}

Sebanyak $1 \mathrm{~mL}$ larutan ferrat dan zat warna azo dengan konsentrasi pada rasio molar yang optimum ditambahkan buffer pada $\mathrm{pH}$ optimum, kemudian larutan dikocok. Larutan diukur absorbansinya dengan spektrofotometer UV-Vis pada panjang gelombang zat warna azo, dengan interval 1 menit selama 30 menit.

\section{Penentuan persentase degradasi zat warna azo}

Penentuan persentase degradasi
zat warna azo dihitung dengan menggunakan rumus :

$\%$ Zat Warna Azo Terdeg radasi $=\frac{[\text { Azo }]_{\text {aval }}-[\text { Azo }]_{\text {sisa }}}{[\text { Azo }]_{\text {aval }}} \times 100 \%$

\section{HASIL DAN PEMBAHASAN}

Sintesis Ferrat $\left(\mathrm{FeO}_{4}\right)^{2-}$ Menggunakan Oksidator NaOCl

Proses sintesis ferrat dilakukan dengan menambahkan $\mathrm{NaOH}$ yang berbentuk pelet ke dalam larutan $\mathrm{NaOCl}$ $5,25 \%$. Spesies besi (Fe) yang akan dioksidasi terdapat dalam larutan $\mathrm{FeCl}_{3}$ yang ditambahkan kemudian. Reaksi yang terjadi dalam sintesis ferrat adalah reaksi oksidasi-reduksi dan dapat dilihat pada reaksi berikut :

$2 \mathrm{Fe}^{3+}+3 \mathrm{ClO}^{-}+10 \mathrm{OH}^{-} \rightarrow 2 \mathrm{FeO}_{4}{ }^{2-}+3 \mathrm{Cl}^{-}$ $+5 \mathrm{H}_{2} \mathrm{O}$

Dalam reaksi tersebut dapat kita lihat bahwa $\mathrm{Fe}^{3+}$ yang berasal dari larutan $\mathrm{Fe}\left(\mathrm{NO}_{3}\right)_{3}$ dioksidasi oleh $\mathrm{NaOCl}$ menjadi $\mathrm{FeO}_{4}{ }^{2-}$. Ferrat hasil sintesis memiliki warna spesifik, yaitu ungu tua. Oleh karena ferrat merupakan larutan berwarna, maka salah satu uji karakterisasi ferrat adalah dengan menggunakan spektrofotometer UV-Vis.

Kondisi pH reaksi pada saat sintesis berlangsung adalah dalam suasana basa yang dilakukan dengan menambahkan padatan $\mathrm{NaOH}$ ke dalam larutan $\mathrm{NaOCl}$. Pada suasana basa, ferrat akan memiliki kestabilan yang lebih baik dibandingkan dalam suasana asam. Hal ini disebabkan karena ferrat hanya akan terbentuk pada suasana basa sedangkan dalam suasana asam, ferrat tidak akan terbentuk dan spesies yang dominan adalah ion $\mathrm{HFeO}_{4}{ }^{-}(\mathrm{Li}, 2005)$. Selama proses sintesis ferrat ini dilakukan, temperatur yang digunakan adalah temperatur kamar, yaitu $\pm 27^{\circ} \mathrm{C}$. Hal ini dilakukan mengingat ferrat adalah senyawa yang sangat labil, sehingga kondisi temperatur yang ekstrim diperkirakan dapat mengganggu kestabilan ferrat.

Larutan ini kemudian dianalisis dengan spektroskopi UV-Vis untuk menentukan panjang gelombang maksimumnya. Pengukuran dilakukan pada rentang panjang gelombang antara $400 \mathrm{~nm}$ sampai $700 \mathrm{~nm}$. Berdasarkan hasil pengukuran diperoleh panjang gelombang maksimum ferrrat adalah 510 nm. Kurva absorbansi ion ferrat pada daerah visibel ditunjukkan pada Gambar 1.

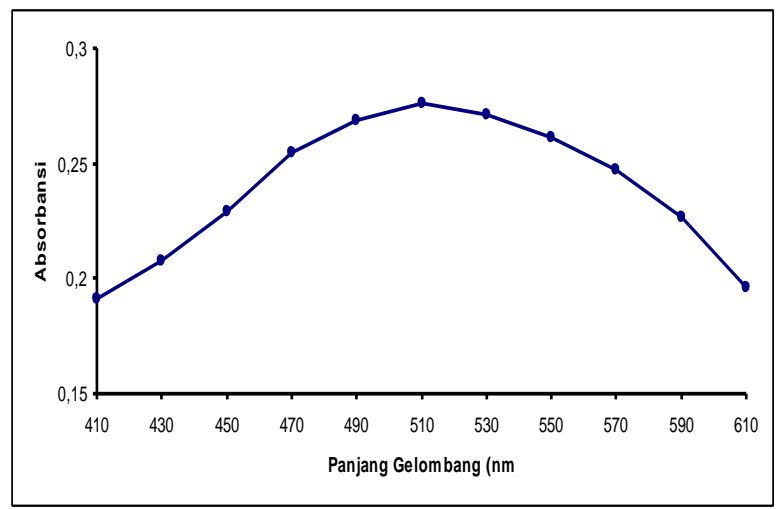

Gambar 1. Kurva absorbansi ion ferrat pada daerah visible

\section{Degradasi Acid Orange 7}

Degradasi zat warna ditandai dengan terjadinya dekolorisasi atau penurunan intensitas warna. Pada Gambar 2 terlihat bahwa acid orange 7 
mengalami dekolorisasi maksimal pada 13 menit dengan kondisi pH 9,8 dan perbandingan rasio molar acid orange 7 dengan ferrat 1:4.

Pada Gambar 2 dapat dijelaskan bahwa reaksi antara acid orange 7 dan ferrat berlangsug relatif cepat, dengan degradasi acid orange $7(98,9 \%)$ terjadi setelah 12 menit, dan diikuti dengan reaksi lebih lanjut secara berangsurangsur pada 13 menit berikutnya.

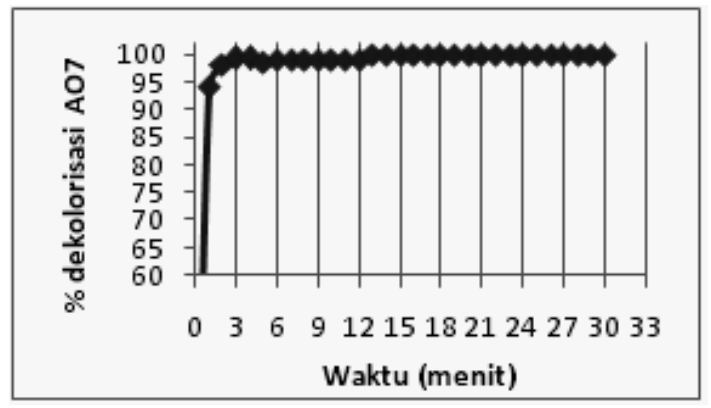

Gambar 2. Degradasi Acid Orange 7

Perlakuan berikutnya adalah mengidentifikasi beberapa produk akhir dari hasil degradasi acid orange 7 menggunakan spektrofotometer UV. Setelah diukur, diperoleh grafik seperti pada Gambar 3. Penelitian yang pernah dilakukan oleh Pinhiero (2004), dilaporkan bahwa produk akhir dari degradasi acid orange 7 dengan menggunakan bakteri Pseudomonas luteola adalah asam sulfanilat dan 1amino-2-naftol.

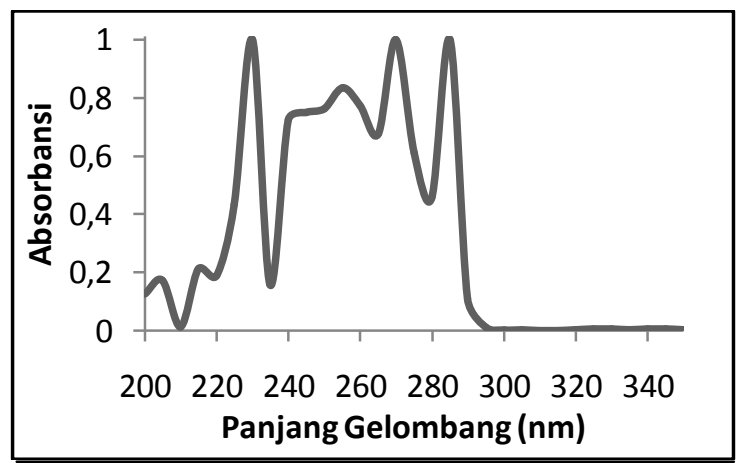

Gambar 3. Spektra Degradasi Acid Orange 7
Berdasarkan grafik tersebut terlihat adanya puncak yang tajam pada panjang gelombang $285 \mathrm{~nm}$. Panjang gelombang ini sesuai dengan panjang gelombang asam sulfanilat (Kristianingsih, 2005). Dari grafik tersebut terlihat bahwa selain asam sulfanilat, terdapat produk lain. Hal ini ditunjukkan dengan adanya puncak pada panjang gelombang $235 \mathrm{~nm}$, di mana panjang gelombang ini menunjukkan panjang gelombang benzene sulfonat. Pada panjang gelombang $270 \mathrm{~nm}$, menunjukkan panjang gelombang senyawa produk yang memiliki kromofor nitrat.

Konstantinou dan Albanis (2004) melaporkan bahwa terbentuknya senyawa baru dari degradasi acid orange 7 dengan menggunakan sistem sinar tampak- $\mathrm{TiO}_{2}$ yaitu asam benzene sulfonat, asam sulfanilat, 1,4-naftoquinon, dan asam ftalat, fumarat, suksinat, maleat, malonat, asam oksalat, asam asetat dan asam formiat.

\section{KESIMPULAN}

Berdasarkan hasil penelitian dan pembahasan maka dapat ditarik kesimpulan bahwa ferrat dapat secara efektif mendegradasi zat warna acid orange 7 pada rasio molar $\mathrm{Fe}(\mathrm{VI})$ : acid orange $=4: 1$. Zat warna acid orange 7 terdegradasi relatif cepat oleh ferrat yaitu pada menit ke-12 dengan persentase degradasi sebesar 98,9\%.

\section{UCAPAN TERIMA KASIH}

Kami mengucapkan terimakasih kepada Unsoed yang telah mendanai penelitian ini melalui skim DIPA BLU MIPA 2009.

\section{DAFTAR PUSTAKA}

Daintith, J., 2005, Kamus Lengkap Kimia (diterjemahkan oleh Achmadi, S.), Penerbit Erlangga, Jakarta. 
Dwiasi, D.W, 2008, Studi Degradasi Zat Pewarna Azo, Metil Orange, Menggunakan Ferrat $\left(\mathrm{FeO}_{4}{ }^{2-}\right)$, Jurnal Ilmiah Kimia Molekul, Vol. 3, No. 1. 2008.

Jiang, J.Q. and Lloyd, B, 2002, Progress In The Development And Use Of Ferrate(VI) Salt As An Oxidant And Coagulant For Water And Wastewater Treatment, Water Res. 36, 1397-1408.

Konstantinou, I.K., and T.A. Albanis, 2004, $\quad \mathrm{TiO}_{2}$-Assisted Photocatalytic Degradation of Azo Dyes in Aqueous Solution : Kinetic and Mechanistic Investigations, A Review. Applied Catalysis B : Environmental. 49, $1-14$.

Kristianingsih, L.W., 2005, Studi Degradasi Zat Pewarna Azo Acid Orange 7 Menggunakan Proses Oksidasi Lanjut, Tesis. MIPAUGM.
Li, C., X.Z. Li, and N. Graham, 2005, A Study Of The Preparation And Reactivity Of Potassium Ferrat. Chemosphere 61 (2005) 537-543.

Panagiota, P. and Graham, J. D. 2002. Ozonation Of Municipal Wastewater Effluents. Wat. Environ. Res. 74, 569-581.

Pinheiro, H.M., E. Touraud, and O. Thomas, 2004, Aromatic Amines From Azo Dye Reduction : Status Review With Emphasis On Direct UV Spectrophotometric Detection In Textile Industry Wastewater, Dyes and Pigments 61, $121-139$.

Sharma, V. K, 2007, Disinfection Performance Of $\mathrm{Fe}(\mathrm{VI})$ In Water And Wastewater : A Review, Water Science \& Technology, 55, 225-232.

Xu, G.R., Y.P. Zhang, dan G.B. Li, 2009, Degradation of Azo Dye Active Brilliant Red X-3B by Composite Ferrate Solution, Journal of Hazardous Materials, 161(23):1299-1305. 